\title{
Identifying priority areas for European resource policies: a MRIO-based material footprint assessment
}

\author{
Stefan Giljum ${ }^{1 *}$, Hanspeter Wieland ${ }^{1}$, Stephan Lutter ${ }^{1}$, Martin Bruckner ${ }^{1}$, Richard Wood ${ }^{2}$, Arnold Tukker ${ }^{3,4}$ \\ and Konstantin Stadler ${ }^{2}$
}

*Correspondence:

stefan.giljum@wu.ac.at

${ }^{1}$ Institute for Ecological Economics, Vienna University of Economics and Business (WU), Vienna, Austria

Full list of author information is available at the end of the article

\begin{abstract}
In the context of the transformation toward a "green economy," issues related to natural resource use have rapidly increased in importance in European and international policy debates. The large number of studies applying economy-wide material flow analysis so far mostly produced aggregated national indicators, making the results difficult to connect to policies, which are often designed for single sectors or consumption areas. This paper provides a detailed assessment of the composition of EU's material footprint in its global context, aiming at identifying the main product groups contributing to overall material consumption and specifying the geographical sources for the raw materials required to satisfy EU's final demand. Based on multi-regional input-output (MRIO) modeling, we apply production layer decomposition to assess supply chains and their structural changes from 1995 to 2011. The global MRIO database used in this study is EXIOBASE 3, which disaggregates 200 products and 163 industries, of which 33 represent material extraction sectors. By that means, we increase the level of detail to a degree where policies can more easily connect to. We find that the generally growing material footprint of the EU was characterized by a dramatic shift regarding the origin of raw materials, with the share of materials extracted within the EU territory falling from 68 \% in 1995 to 35 \% in 2011. In 2011, raw materials extracted in China to produce exports to the EU already contributed an equal share to EU's material footprint as material extraction within the EU itself. Import dependency is most critical for the material group of metal ores, with only $13 \%$ of all metals required as inputs to EU final demand stemming from within the EU. Regarding product composition, construction was confirmed as the most important sector contributing to the material footprint, followed by the group of manufacturing products based on biomass. Materials embodied in service sector activities together contributed a quarter to the total material footprint in 2011, making services an important, but currently disregarded area for European resource policies. We also find that supply chain structures became more complex over time, with a growing part located outside the EU territory.
\end{abstract}

Keywords: Material footprint, Multi-regional input-output analysis,

Production layer decomposition, Supply chains, Resource policies 


\section{Background}

\subsection{Policy background}

Economic development in the past decades was characterized by steadily increasing levels of global resource use and rising human pressures on global ecosystems (Giljum et al. 2014; Krausmann et al. 2009; UNEP 2011a). Driven by rapidly growing levels of material consumption in emerging economies together with continued high levels of per capita resource use in the industrialized world, the global economy is also characterized by increasing competition between world regions regarding the access to raw materials. Against this background issues related to material consumption and resource productivity have rapidly increased in importance in European and international policy debates in the past few years.

In response to these environmental and economic challenges, numerous policy initiatives have been introduced aiming at significantly increasing resource efficiency to reduce negative environmental impacts, while addressing issues related to material supply security and import dependency. Examples for these strategies on the international level with a strong focus on resource efficiency include the "Green Economy" concept promoted by UNEP (2011b) or the "Green Growth Strategy" of the OECD (2011).

The most important policy strategy at the European level promoting resource efficiency is the Commission's Flagship Initiative "A resource-efficient Europe" (European Commission 2011b) as well as the subsequent "Roadmap to a resource-efficient Europe" (European Commission 2011c), both part of the implementation of the "Europe 2020" strategy. The overall objective of the Roadmap is to ensure that "by 2050 the EU's economy has grown in a way that respects resource constraints and planetary boundaries" and to identify priority areas and actions "to put us on a path to resource efficient and sustainable growth" (p. 3). Three consumption areas receive particular attention in the Roadmap: food, housing and mobility. The food value chains are identified as causing major global impacts, in particular related to the production of animal-based products. Regarding the housing and building sector, the Commission recognizes the significant material flows related to construction and maintenance activities of buildings. It is argued that the aggregated impacts of housing and infrastructure account for around 15-30 \% of all environmental pressures caused by European consumption. The third high-impact area regarding resource use identified in the Roadmap is mobility with its high demand for material-intensive transport infrastructure and the high dependency on fossil fuels.

In some consumption areas, notably food consumption, the Commission acknowledges that European consumption causes negative global impacts. In general, however, the Commission is rather concerned about the negative impacts on the EU economy caused by international developments such as restrictions in raw material availability or increasing raw material and food prices (European Commission 2011a). The most prominent related policy strategy focusing on aspects of import dependency, resource supply and access to natural resources is the Raw Materials Initiative (European Commission 2008, 2011d). In these documents, the Commission focuses on critical materials, in particular metal ores with high import dependency rates and high relevance for European industries, and describes measures to secure and improve access to these raw materials. In the initiative, certain materials with specifically high dependency rates are identified, such as indium, titanium and niobium, where the EU faces an import dependency rate 
of $100 \%$ (European Commission 2008). However, the supply and dependency aspects are solely tackled from a perspective of direct imports and inputs into the European economy, not from a supply chain perspective. Issues such as supply chain security and dependency on indirect supplies via imported manufactured goods are not mentioned.

Recently, the EU has also committed itself to the vision of a circular economy and has presented a package of legislative and voluntary measures. This initiative aims at closing the loops of materials and thus maintaining the value of resources and products as long as possible within the economy, while minimizing the amount of generated waste (European Commission 2015).

Given the increased demand for robust measures from the policy side, discussions on the most suitable indicators to measure resource use, productivity and criticality of raw materials are intensively ongoing. In recent years, awareness of policy makers generally increased regarding the significance not only of materials and products directly used by a national economy, or a regional economy such as the EU, but also of indirect resource use required along supply chains and embodied in internationally traded products. Consideration of all indirect effects leads to a consumption-or footprint-perspective, allowing illustrating the global impacts related to final demand. As a consequence, there is increasing research on the differences between production-based versus consumption-based trends of material use and its relation to GDP, in order to evaluate whether decoupling is being achieved (UNEP 2011a). Recent results suggest that assessments of decoupling can lead to very different results when measured with different indicators. Industrialized countries and regions, such as the USA or the EU, have in general achieved a relative decoupling when measured with indicators of direct material use, i.e., production-oriented indicators. Some countries, such as Japan, were even able to reduce direct material use in absolute terms (Giljum et al. 2014; Steinberger et al. 2013). However, when consumption-based-or footprint-type-indicators are applied, the decoupling performance is much weaker or even reversed, with material footprints growing faster than GDP (Wiedmann et al. 2015).

\subsection{Methodological background}

A rapidly growing body of literature assessing material flows considers indirect material flows embodied in internationally traded products and applies consumption-based or footprint-type indicators with the objective of providing complementary information for the design of resource policies. Studies include national assessments (for example, Kovanda and Weinzettel 2013; Schaffartzik et al. 2014), EU-wide studies (Arto et al. 2012; Schoer et al. 2012) as well as international assessments (for example, Bruckner et al. 2012; Giljum et al. 2015; Wiedmann et al. 2015). Existing studies so far mostly produced aggregated national indicators on material consumption and resource productivity, making it difficult to use MFA results for policy making, which is often focused on specific sectors or consumption areas. The drivers underlying these aggregated indicators as well as the hotspot products and supply chains mostly contributing to the overall results have rarely been investigated (the study by Acosta-Fernández (2007) on identifying sectoral hotspots of material use in the German economy and related priority areas of policy action is one of the very few exceptions). A more detailed understanding of developments on the level of economic sectors and supply chains is essential to identify 
areas in the production-consumption system, which needs to be transformed, if absolute levels of material consumption should be reduced.

Several methods are available to calculate consumption-based MFA indicators, each having its advantages and drawbacks (Lutter et al. 2016; Schoer et al. 2013). Three methodological approaches have been developed and applied so far: coefficient-based approaches building on process analysis, environmental input-output analysis and hybrid approaches combining elements from both approaches. Coefficient-based approaches allow calculating material footprint-type indicators at a very high level of detail, as coefficients can be calculated for a large number of single products without any restrictions of pre-defined sectors or product groups. However, material input coefficients are difficult to calculate for higher manufactured products and services with complex supply chains. Coefficients are often not specific regarding geographical origin of raw materials - in many cases, the geographical origin of a raw material is different to the geographical origin of an imported manufactured good. Furthermore, based on coefficient approaches, it is likely that the calculated total of global environmental pressures related to consumption does not equal the pressures of worldwide production.

Input-output analysis, in particular in the context of multi-regional input-output (MRIO) models, has the key advantage of depicting the whole global economy and thus allowing calculating material footprints for all products and sectors independently of the complexity of the underlying supply chains. MRIO models also avoid double counting as supply chains are clearly distinguished from each other. Furthermore, these models allow determining the geographical origin of each raw material related to the final demand of a country or region. For these reasons, in this paper, we apply a MRIO-based approach, based on the database EXIOBASE, which was specifically developed for environmental-related assessments and distinguishes a large number of different raw materials (see Sect. 2 for more details).

\subsection{Objectives}

This paper provides a detailed assessment of the composition of the EU's material consumption in a global context, with the aim to identify primary product groups contributing to the EU's global material footprint. We further aim at assessing the supply chain structure of various product groups, thus identifying in which parts of the supply chain major material extractions take place. The temporal and geographical coverage of EXIOBASE further allows for the assessment of changes over time, for example regarding the importance of raw material inputs stemming from non-European countries. This analysis elucidates whether outsourcing of environmental pressures through international trade occurred and illustrates which world regions serve as major suppliers of raw materials directly and indirectly required to satisfy EU's final demand. Based on the empirical assessment, we aim at reflecting current priority areas of EU resource policy making and at deriving recommendations for the priority areas and topics the EU should focus in its future policy efforts.

The remainder of the paper is structured as follows: Section 2 starts with a description of the MRIO and material flow data as well as of the applied analytical methods. Section 3 presents the various results from the MRIO assessment both on the level of overall EU material consumption and on the level of different product groups and 
their underlying supply chains. It also discusses the results in the context of current EU resource policy priorities. The final Sect. 4 concludes.

\section{Methods}

\subsection{MRIO database}

For the material footprint assessments in this paper, we apply the MRIO database EXIOBASE (Tukker et al. 2013, 2014; Wood et al. 2015), a very detailed global MRIO database, developed in particular for environmental assessments of the EU. With 200 commodities and 163 industries, of which 33 represent the primary sector of the economy, EXIOBASE provides the highest consistent level of product and sector detail by country across all currently available MRIO models (see Additional file 1: Full list of EXIOBASE products and product groups). In EXIOBASE, agricultural activities are represented by 15 product groups and thus in a similar detail as in the GTAP model (Andrew and Peters 2013). In contrast to most available MRIO tables, which aggregate mining and quarrying of fossil fuels and mineral resources into one or two sectors (see, Giljum et al. 2015), EXIOBASE contains 12 extraction sectors for fossil fuels, 8 metal extraction sectors and three sectors representing the extraction of industrial and construction minerals. It thus represents a major advantage in terms of detail for assessing global material flows.

On the downside, EXIOBASE only details 44 countries (28 EU member states plus 16 major trade partners of the EU, together adding up to around $95 \%$ of global GDP) and covers all other countries in the form of five rest-of-the-world regions (see Additional file 2: Full list of EXIOBASE countries and regions). In contrast, the Eora database (Lenzen et al. 2013) distinguishes 187 countries/regions, and the latest version of GTAP (Narayanan et al. 2015) separately models 140 countries and regions. However, for assessments of EU's global environmental impacts, EXIOBASE is a very suitable database. In this paper, we aggregated all results of the EU-28 countries into one region, in order to provide an overall assessment of the EU as a whole. Future research may focus on specific patterns of single EU countries.

Furthermore, a high level of regional detail as provided by Eora or GTAP is required to avoid errors caused by product and price inhomogeneity between countries in a certain region and becomes relevant when there are large trade flows from those regions. We argue that for the analysis of the flows of raw materials, limited trade flows to the EU come directly from the aggregate regions, and because those materials traded have prices being mainly determined on global markets, price differences between countries within an aggregate region will be smaller compared to price differences between raw materials. Consequently, for this study a high level of commodity detail is regarded as more relevant.

In this paper, we apply EXIOBASE in its version 3.1, covering the time period of 1995 to 2011. In order to adequately represent the global economic structure over time, EXIOBASE 3.1 combines several data sources to capture economic changes. Principle data include macroeconomic accounts (GDP, total trade, final demand from UN SNA database) and other detailed data sources (IEA, FAOSTAT, Comtrade, various mining databases, BACI and others) to estimate product and industry output over time as well as product-specific bilateral trade. The structural change of domestic economies was estimated by inter/extrapolate observed changes of national IO tables over time (for 38 
of the 44 EXIOBASE countries, i.e., excluding Mexico, Luxembourg, Croatia, Indonesia, Turkey and Canada). Inconsistencies within the database caused by conflicting data sets were resolved by balancing the systems using a flexible mathematical programming approach where information gain is minimized (Lenzen et al. 2009). The estimation of the uncertainty associated with such techniques has not received a great deal of attention in research, albeit Lenzen et al. (2010) have attempted to capture some of the impact of these techniques for the case of greenhouse gas emissions.

\subsection{Material extraction data and indicators}

The material extensions in EXIOBASE were compiled using the WU Global Material Flow database (WU 2015, available at www.materialflows.net). This database contains material extraction data for all countries worldwide, for all raw material categories and in annual time series from 1980 to 2013. The database is compiled following the standards of economy-wide material flow accounting (EW-MFA) provided by Eurostat and the OECD (EUROSTAT 2013; OECD 2007).

Four main data sources are used for the compilation of the database-the British Geological Survey (BGS) and the US Geological Survey (USGS) for metal and mineral data; the International Energy Agency (IEA) for the data on fossil fuels; and the FAO for the data on biomass extraction. The quality of the material extension data varies across the different material categories, depending on the data source and necessary estimation or manipulation steps. In general, the primary data from BGS, USGS, IEA and the FAO are of good quality. However, for some types of material extraction, estimation techniques need to be applied due to a lack of official statistics. This holds especially true for the cases of the extraction of construction minerals, biomass uptake by rooming animals (grazing) and the generation of by-products from agricultural harvest. For more information on the compilation of the underlying material flow database, for example, regarding the treatment of coupled production in metal mining, see Additional file 3: Technical details on the compilation of the global material flow database and WU (2015).

In order to generate the physical satellite to the MRIO system, the around 380 categories of primary raw material extraction data are aggregated into the 33 extraction sectors of EXIOBASE (see Additional file 4: Correspondence table between raw materials and EXIOBASE sectors). All MFA data are fed into the MRIO system in the unit of $1000 \mathrm{t}$.

The main indicator generated with the MRIO system is the economy-wide indicator raw material consumption (RMC), also known as material footprint (Giljum et al. 2015; Wiedmann et al. 2015). The RMC or material footprint indicator comprises all domestically and foreign raw materials that were directly and indirectly required to produce goods and services of the EU final demand. The material footprint thus expresses the amounts of materials embodied in final demand and aims at understanding the socioeconomic drivers, such as private or public consumption, of raw material extraction. It is important to note that this approach differs from other types of material flow analysis, which aim at physically tracking actual flows of certain raw materials or substances (for example, Graedel et al. 2015; Laner et al. 2015). Furthermore, it needs to be emphasized that the approach applied in this paper focuses on the footprint of primary materials. Integrating secondary raw materials from recycling in this assessment would require additional material flow data (see Haas et al. 2015). 
In MFA, indicators are generally decomposed into four major material categories, i.e., biomass, fossil fuels, minerals and metal ores. In this paper, we present indicators both on the aggregated level across all materials and on the level of the four main material groups.

\subsection{Analytical methods}

The data analysis starts on the aggregated level illustrating the overall material footprint time series of the EU followed by decompositions into the four main material categories, into sectors and product groups as well as into source countries for raw materials. The latter are identified for the total material footprint and separately for each aggregated material group. This is carried out for the whole time period of 1995-2011 in order to determine whether and to which regions the EU has outsourced material extraction via international trade. We also analyze the sector composition, identifying the sector groups contributing most to the EU's material footprint, and how this composition changed over time, thus analyzing structure and temporal dynamic of the EU material footprint.

Apart from these standard analyses, MRIO models representing the entire global economy and all underlying supply chains allow for the application of additional analytical tools. These tools assess supply chain structures underlying the total material footprint of a product or product group and thus visualize the type and complexity of intermediate deliveries. In this paper, we apply production layer decomposition, PLD (compare Lenzen and Crawford 2009; Llop and Ponce-Alifonso 2015; Wiedmann et al. 2009), which is an aggregated form of structural path analysis (SPA). SPA allows opening up the black box of national and international supply chains uncovering the largest inter-sector and inter-country pathways of flows of goods and services through the global economy (Lenzen 2007; Peters and Hertwich 2006). The benefit of the very high level of detail through identifying all paths in the global economy related to final demand in a certain country or region entails the disadvantage of producing very large data sets, in particular when an SPA is performed for various types of raw materials and with timeseries data.

Therefore, in order to derive more general conclusions from the MRIO model in terms of the biophysical dimension of supply chain structures and temporal dynamics, in contrast to SPA, production layer decomposition does not calculate the "weight" of single paths but aggregates all material extractions occurring at discrete supply chain layers. In its core, PLD can be expressed as:

$$
e_{k, m}=\hat{s}_{m} A^{k} \hat{y}
$$

where $e_{k, m}$ equals the material extraction of raw material group $m$ on layer $k$ along the path of a product or product group, which directly or indirectly serves final demand. $\hat{s}$ represents the diagonalized direct intensities of material group $m$, which results from dividing the domestic extraction vector of $m$ by the sectors gross output vector $x$, and where $\hat{x}=L \hat{y}$, with $L$ being the Leontief inverse matrix and $\hat{y}$ the diagonalized final demand vector. Subsequently, $\hat{s}_{e}=\hat{m} \hat{x}^{-1} . A$ is the technical coefficients matrix. For the case of layer 0, i.e., direct deliveries material extraction sectors to final demand: $e_{k=0, m}=\hat{s}_{m} I \hat{y}$, where $I$ represents the identity matrix. 
Due to the fact that there are an infinite number of layers, we calculate the residual $e_{r+}$ via

$$
L_{r+}=L-I-\sum_{k=1}^{r} A^{k}
$$

and

$$
e_{r+, m}=\hat{s}_{m} L_{r+} \hat{y}
$$

where $r$ is the selected threshold regarding the number of layers separately analyzed.

We can then relate the single-layer results $e_{k}$ to the overall material footprint MF through their summation:

$$
\mathrm{MF}=\left(\sum_{k=0}^{r-1} e_{k}\right)+e_{r+}
$$

Moreover, we can use production layer decomposition to disaggregate the individual layer results into the amount of raw materials extracted within and outside the EU.

\section{Results and discussion}

\subsection{Results}

The results section of the paper is structured by starting with aggregated results for the EU material footprint and subsequently decomposing the overall trends in various dimensions. The first perspective is the origin of the various raw materials related to EU final demand, followed by an analysis of the main products and product groups contributing to the EU material footprint. Based on the PLD, we then illustrate the structure of supply chains behind each of the aggregated product groups and assess how the layer structure evolved over time. For selected product groups, we also discuss how the distribution between materials extracted in the EU versus abroad changed on each layer from 1995 to 2011. Finally, we provide a disaggregation of the material footprint layers by the main material categories, thereby analyzing the structural differences in the use of certain material groups in the economic system.

Figure 1 illustrates the overall development of the material footprint of the EU, disaggregated by the four main material groups (top) and by the countries and world regions, where the raw materials were extracted to directly and indirectly serve final demand in the EU (bottom).

The overall material footprint of the EU rose from 8.4 billion tonnes in 1995 to 12.2 billion tonnes in 2011. After a 5-year period of relatively strong increases between 2002 and 2007, the impact of the economic crisis in 2008 and in particular in 2009 is clearly visible in the overall trend. In these two years, the EU material footprint dropped by around $13 \%$ compared to the maximum level of 2007. In 2011, the EU material footprint regained an absolute level that was equal to the level in 2005/2006.

When analyzed by main material groups, it is clearly visible that the category of industrial and construction minerals contributes the largest share to the material footprint (54 \% in 2011, up from $43 \%$ in 1995). Minerals were also the group that most 


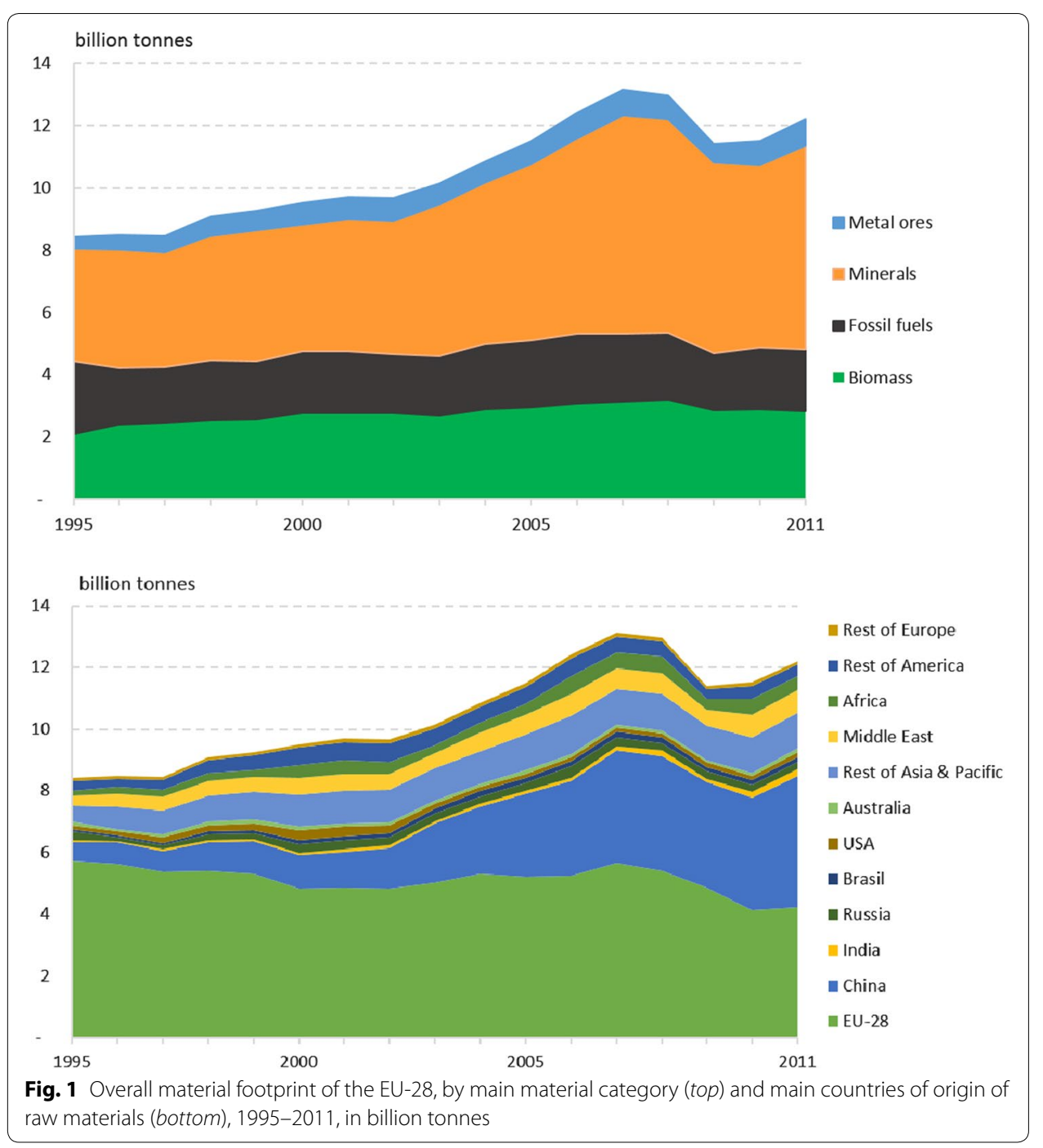

significantly declined in the period of the economic crisis, contributing around half of the overall reduction between 2007 and 2009. This indicates the strong impact of the crisis on the construction sector, in particular in countries such as Spain, Italy or the UK, but also in some Eastern European countries such as Romania. Direct and indirect extraction of biomass grew by $35 \%$ over the whole time period, and the required metal ores to satisfy EU final demand was increased by $116 \%$, but from a lower absolute level. Fossil fuels were the only category where the EU consumed less in 2011 compared to 1995 (-14\%).

From the perspective of the origin of raw materials, dramatic shifts can be observed over the analyzed time period. The share of raw materials that were extracted within the territory of the EU fell significantly from 68 \% in 1995 to $35 \%$ in 2011. This illustrates that today around two-thirds of the raw materials that are directly and indirectly needed to satisfy European final demand is extracted in other world regions. As illustrated in Fig. 1 (bottom), the most significant shift occurred between the EU and China, which in 2011 already contributed an equal amount of raw materials related to EU's final demand 
for goods and services. This particular pattern is closely related to the current development stage of China, which-as a fast-growing emerging market-is in the process of building up its housing, transport and energy infrastructure. On the one hand, this leads to significant amounts of raw materials required for investments and capital formation, which dominate China's own material footprint (see Giljum et al. 2015). On the other hand, construction materials also serve as indirect inputs to manufacturing industries, which produce goods exported to the EU (see also Wang et al. 2014; Wiedmann et al. 2015). This indirect flow of construction materials grew from around 230 million tonnes in 1995 to more than 3 billion tonnes in 2011 and was thus far above flows of other key raw materials extracted in China and serving EU final demand, such as coal (394 million tonnes) or iron ores (157 million tonnes).

As the material footprint calculations can be performed separately for various raw materials and then be aggregated into the four major material groups, Fig. 2 depicts the regional origin of raw materials serving the EU final demand for biomass, fossil fuels, minerals and metal ores.

The overall development as well as the regional patterns of origin differs significantly across the four main material categories. However, two general trends can be observed for all four raw material groups. First, extraction of raw materials within the EU decreased, while the material footprint increased for all four categories except fossil fuel consumption, which in 2011 was on an equal level as in the mid-1990s. This implies that the EU is to an increasing extent directly as well as indirectly dependent on imports from other world regions. Second, the Asia and Pacific region serves as the main source

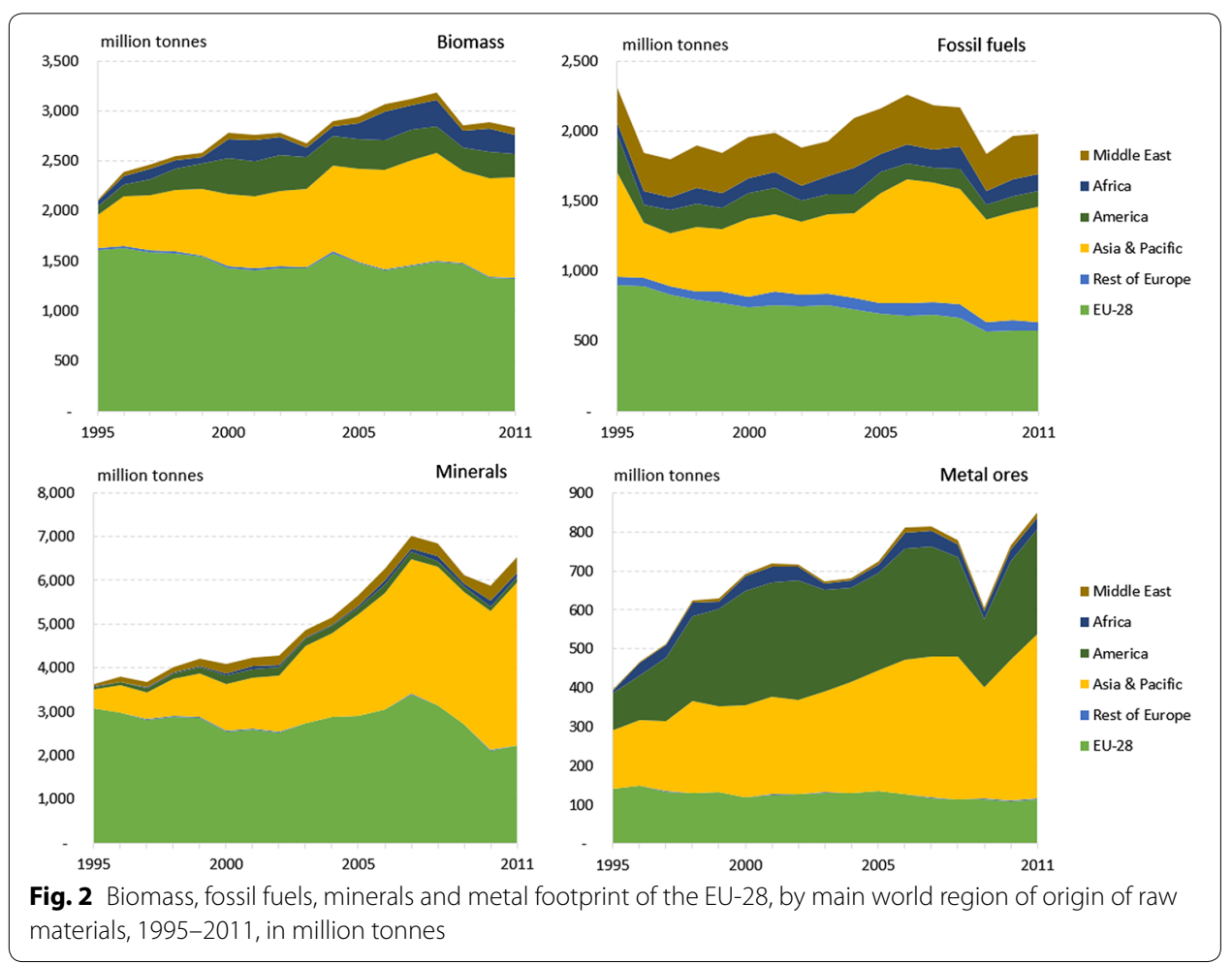


of raw materials embodied in European imports across all four major categories, with China playing an outstanding role.

Biomass is the material category, where the highest share of raw materials still stems from within the EU territory. The share was 76 \% in 1995 and decreased to $47 \%$ in 2011. With $35 \%$ in 2011, biomass originated to a significant extent from Asia, up from $15 \%$ in 1995. China played an important role contributing $16 \%$ to biomass extraction in 2011, in particular related to the production of cattle and other meat. Three percentage of biomass in the EU material footprint was extracted in India with a similar product focus as in the Chinese case. With $1 \%$, Indonesia was the third largest Asian contributor, with a clear focus on the sector of "oil seeds," i.e., palm oil. Smaller amounts of biomass were embodied in imports from America and Africa.

Fossil fuels extraction within the EU decreased significantly, from around 900 million tonnes in 1995 to around 570 million tonnes in 2011, in particular due to a decrease in coal mining. With $41 \%$, the Asia and Pacific region made up the largest fraction of fossil fuels embodied in EU final demand in 2011. Fossil fuels embodied in imports from China were rapidly increasing in the 2000 s and made up $23 \%$ of the total fossil fuel footprint of the EU-28 in 2011. These fossil fuels included, for example, coal (394 million tonnes in 2011) that was extracted in China and used in electricity production, which is then embodied in Chinese exports. Russia also plays an important role as a direct exporter of particularly natural gas to the EU. The Middle East contributed $15 \%$ to the fossil fuel footprint in 2011.

Minerals extraction within the EU also showed a decreasing trend, with a particularly sharp decrease during the years of the economic crisis, underpinning the argument above that the construction sector in many EU countries was one of the most effected parts of the economies. At the same time, the minerals embodied in imports from the Asia and Pacific region grew almost by a factor of 5 . With more than 3 billion tonnes in 2011, China alone contributed $48 \%$ to the total EU mineral footprint, almost exclusively in the categories of construction materials, such as sand, gravel and stone.

From a European policy perspective, the situation regarding metal ores can be regarded as most critical, as Europe has only a minor production of metals within its territory and is thus heavily dependent on imports from other world regions. In 2011, only $13 \%$ of all metals required as direct and indirect inputs for products and services finally consumed in the EU stemmed from within the European territory. Again, the Asia and Pacific region plays the most important role as a raw material provider (50\%). Most important extraction countries are China, which accounts for $27 \%$ of total EU metal footprint, mostly in the categories of iron ore and copper. Australia delivered $6 \%$ of metals serving as indirect inputs to EU final demand, with iron ore, copper and precious metals being the most important commodities. Three percent of the metal footprint originated in Indonesia, dominated by lead and zinc. Thirty-two percentage of metals embodied in EU's final demand were extracted in the Americas, with Latin American countries providing almost three quarters, mostly iron ore, copper, lead, zinc and precious metals.

In Fig. 3, we turn to another dimension, which the MRIO model allows to put into focus, i.e., the product groups contributing to the material footprint of the EU. In order to facilitate visualization, we aggregated the 200 EXIOBASE products into 11 broad product groups (see Additional file 1: Full list of EXIOBASE products and product groups). 


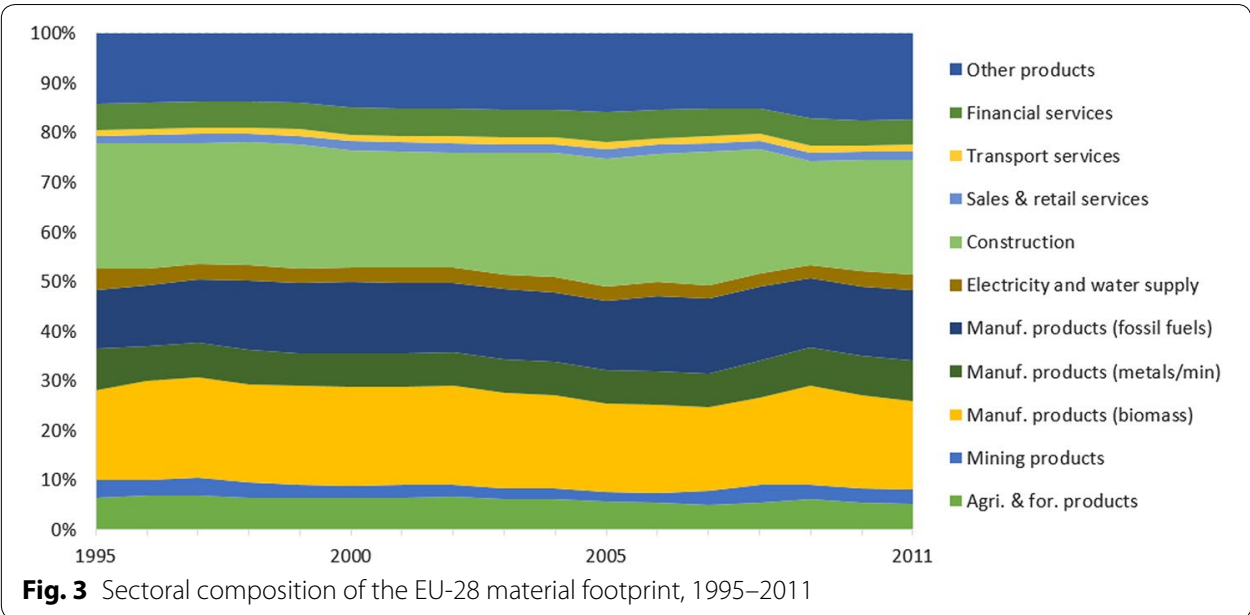

Figure 3 illustrates that the composition of the EU material footprint in terms of aggregated product groups remained relatively stable across the observed time period, despite the overall growing material footprint (compare Fig. 1 above). The main aggregated sector contributing to the material footprint was construction, which held a share of $25 \%$ in 1995, falling slightly to $23 \%$ in 2011 . Construction was followed by the group of manufacturing products based on biomass, most importantly from food-processing sectors. Its share was $18 \%$ in 2011, similar to the contribution in 1995. Manufacturing of products mainly based on fossil fuels ranked third in 2011, with a share of $14 \%$. Most important products were motor gasoline with a material footprint of 189 million tonnes, followed by diesel oil (92 million tonnes). The fourth biggest contributing sector was the large group of manufacturing products based on metals and minerals (8\%). With a material footprint of 393 million tonnes, motor vehicles were the most important product group within this aggregated sector, followed by machinery and equipment (232 million tonnes) and radio, television and communication products (129 million tonnes). The contribution of agriculture and forestry products to the EU material footprint in 2011 was $5 \%$, than that of mining products $3 \%$. Although raw materials are extracted only in these two aggregated sectors (see Fig. 4; Table 2), the overwhelming part of the extracted raw materials are not directly delivered to final demand, but purchased by other sectors of the economy for further processing. Materials embodied in service sector activities together contributed $25 \%$ to the total material footprint, as the group of "other products" mainly contains service sectors, including the large service sectors of health, education and public administration and defense (see Table 1 for more details).

As indicated in the introduction, one key strength of EXIOBASE is the very high product detail. In Table 1, we further decompose the product groups contributing to the EU material footprint and show the top 30 EXIOBASE products (the full list with the footprints all EXIOBASE products can be found in the Additional file 5: Detailed material footprint (MF) results).

These 30 products made up around $80 \%$ of the total EU material footprint in 2011. Table 1 indicates that among the top 30 contributing products, almost all of the 11 aggregated product groups are represented. The product "construction work," which is identical to the aggregated group "construction" as illustrated above, constitutes by far the 


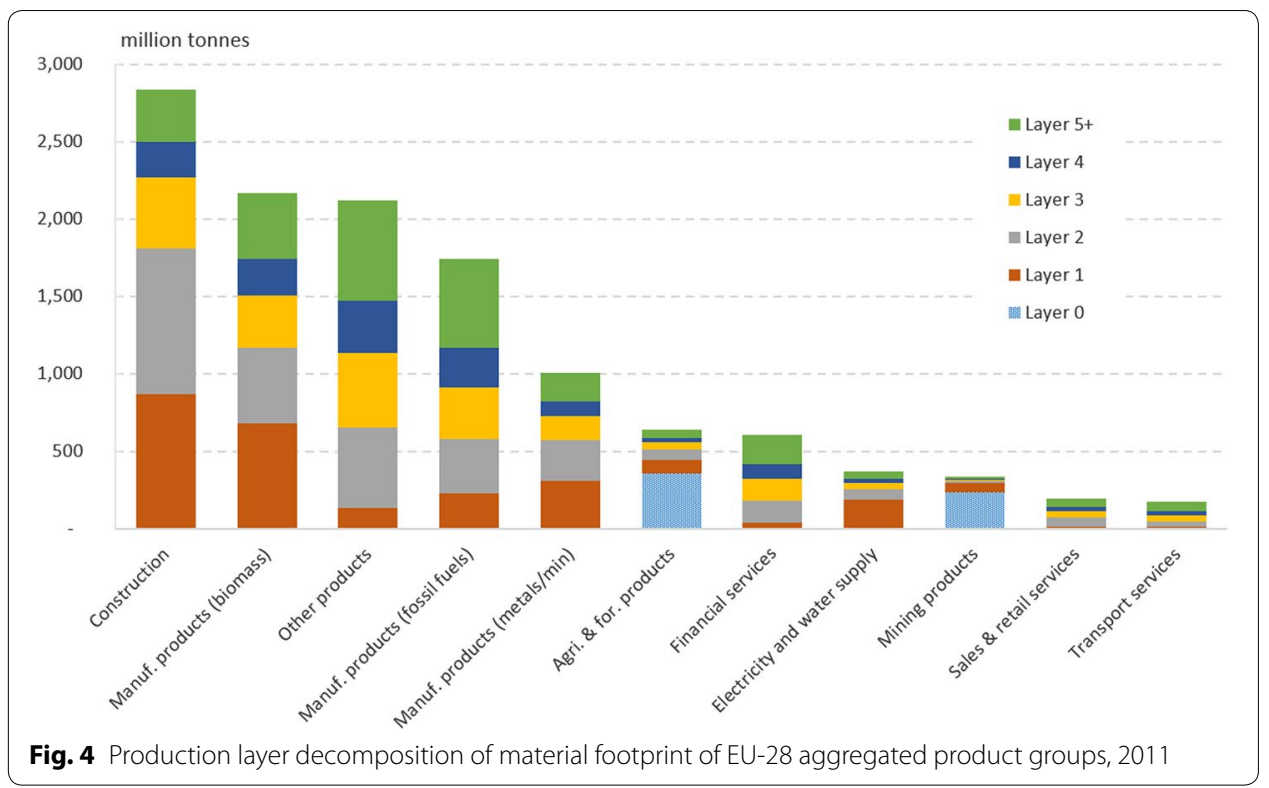

largest product group in the overall EU material footprint (23.2\% in 2011). Construction had both a high share in total EU final demand (9.9\%) as well as a high material intensity or almost $2.3 \mathrm{~kg}$ of direct and indirect material extraction required to produce one Euro of final demand. Given this huge contribution of just one product, it would be desirable to further split up this product group.

It is interesting to note that on the more detailed sector level, service sectors are also found among the top contributors. For example, health and social work services ranked second in the product list, with a contribution of $6.6 \%$ to the total material footprint in 2011. This sector contributed $12.8 \%$ to EU's monetary final demand in that year; however, material intensity was significantly lower (half a $\mathrm{kg}$ of material input per $€$ ). The reason, why this sector has a significant material footprint is that the provision of services in the health sector requires a large number of material-intensive products serving as indirect inputs, including, for example, chemical and pharmaceutical products. Also, food provision in hospitals and other social institutions induces significant flows of biomass, with meat and animal products contributing most to the biomass footprint. Apart from health and social services, also public administration and defense (4.5\%) as well as real-estate services (3\%) has significant shares in the overall material footprint of the EU-28.

Following aggregated product groups such as "food products nec" and "chemicals nec," some specific manufacturing product groups are also located among the top contributors. They include motor vehicles (with a share of $3.2 \%$ ) and machinery (1.9\%). Animal products, which are well known for their high material footprint (Lettenmeier et al. 2014), are not found among the top 10 EXIOBASE products. This fact is a consequence of the construction principles of EXIOBASE, which further split up environmentally sensitive products. In fact, EXIOBASE contains 11 products related to production of meat and dairy products. If the material footprint of these sectors is again aggregated, animal products together contribute almost 900 million tonnes, or $7.1 \%$, to the total material footprint of the EU-28 and rank second after construction. 
Table 1 Top 30 products contributing to the EU-28 material footprint (MF), values of final demand (FD) and material intensities (kg/€), 1995 and 2011

\begin{tabular}{|c|c|c|c|c|c|c|}
\hline \multirow[t]{2}{*}{ Product } & \multirow[t]{2}{*}{ Product group } & \multirow{2}{*}{$\begin{array}{l}\text { MF } 1995 \\
1000 t\end{array}$} & \multirow{2}{*}{$\begin{array}{l}\text { MF } 2011 \\
1000 t\end{array}$} & \multirow{2}{*}{$\begin{array}{l}\% \text { change } \\
1995-2011\end{array}$} & \multirow{2}{*}{$\begin{array}{l}\text { FD } 2011 \\
\text { million } €\end{array}$} & \multirow{2}{*}{$\begin{array}{l}\text { Intensity } \\
2011 \\
\text { kg per } €\end{array}$} \\
\hline & & & & & & \\
\hline Construction work & Construction & $2,135,125$ & $2,834,192$ & 33 & $1,239,222$ & 2.29 \\
\hline $\begin{array}{l}\text { Health and social work } \\
\text { services }\end{array}$ & Other products & 371,974 & 799,155 & 115 & $1,607,816$ & 0.50 \\
\hline Food products nec & $\begin{array}{l}\text { Manuf. products } \\
\text { (biomass) }\end{array}$ & 542,018 & 654,621 & 21 & 280,307 & 2.34 \\
\hline $\begin{array}{l}\text { Public administration and } \\
\text { defense services }\end{array}$ & Other products & 357,479 & 543,163 & 52 & $1,036,643$ & 0.52 \\
\hline Chemicals nec & $\begin{array}{l}\text { Manuf. products (fos- } \\
\text { sil fuels) }\end{array}$ & 234,641 & 509,761 & 117 & 157,823 & 3.23 \\
\hline $\begin{array}{l}\text { Motor vehicles, trailers } \\
\text { and semi-trailers }\end{array}$ & $\begin{array}{l}\text { Manuf. products } \\
\text { (metals/min) }\end{array}$ & 217,156 & 393,023 & 81 & 348,919 & 1.13 \\
\hline Real-estate services & Financial services & 311,943 & 362,505 & 16 & $1,113,134$ & 0.33 \\
\hline $\begin{array}{l}\text { Furniture and other } \\
\text { manufactured products } \\
\text { nec }\end{array}$ & $\begin{array}{l}\text { Manuf. products } \\
\text { (metals/min) }\end{array}$ & 149,487 & 277,609 & 86 & 240,462 & 1.15 \\
\hline $\begin{array}{l}\text { Membership organization } \\
\text { services nec }\end{array}$ & Other products & 128,809 & 236,885 & 84 & 455,624 & 0.52 \\
\hline $\begin{array}{l}\text { Machinery and equip- } \\
\text { ment nec }\end{array}$ & $\begin{array}{l}\text { Manuf. products } \\
\text { (metals/min) }\end{array}$ & 194,722 & 232,110 & 19 & 206,048 & 1.13 \\
\hline Education services & Other products & 145,041 & 222,463 & 53 & 893,586 & 0.25 \\
\hline $\begin{array}{l}\text { Recreational, cultural and } \\
\text { sporting services }\end{array}$ & Other products & 117,288 & 218,279 & 86 & 496,697 & 0.44 \\
\hline Vegetables, fruit, nuts & $\begin{array}{l}\text { Agri. and for. prod- } \\
\text { ucts }\end{array}$ & 170,744 & 193,087 & 13 & 79,544 & 2.43 \\
\hline Motor gasoline & $\begin{array}{l}\text { Manuf. products (fos- } \\
\text { sil fuels) }\end{array}$ & 229,335 & 188,913 & -18 & 129,213 & 1.46 \\
\hline Products of meat cattle & $\begin{array}{l}\text { Manuf. products } \\
\text { (biomass) }\end{array}$ & 176,350 & 185,881 & 5 & 25,177 & 7.38 \\
\hline $\begin{array}{l}\text { Hotel and restaurant } \\
\text { services }\end{array}$ & $\begin{array}{l}\text { Sales and retail } \\
\text { services }\end{array}$ & 108,763 & 175,816 & 62 & 605,336 & 0.29 \\
\hline Wearing apparel; furs & $\begin{array}{l}\text { Manuf. products } \\
\text { (biomass) }\end{array}$ & 109,155 & 170,524 & 56 & 160,629 & 1.06 \\
\hline Meat products nec & $\begin{array}{l}\text { Manuf. products } \\
\text { (biomass) }\end{array}$ & 93,166 & 155,681 & 67 & 75,501 & 2.06 \\
\hline Fish products & $\begin{array}{l}\text { Manuf. products } \\
\text { (biomass) }\end{array}$ & 77,426 & 155,457 & 101 & 89,126 & 1.74 \\
\hline Products of meat poultry & $\begin{array}{l}\text { Manuf. products } \\
\text { (biomass) }\end{array}$ & 79,197 & 136,148 & 72 & 72,534 & 1.88 \\
\hline $\begin{array}{l}\text { Radio, television and } \\
\text { communication equip- } \\
\text { ment }\end{array}$ & $\begin{array}{l}\text { Manuf. products } \\
\text { (metals/min) }\end{array}$ & 54,644 & 129,304 & 137 & 128,149 & 1.01 \\
\hline Dairy products & $\begin{array}{l}\text { Manuf. products } \\
\text { (biomass) }\end{array}$ & 80,227 & 122,533 & 53 & 78,554 & 1.56 \\
\hline Electricity by coal & $\begin{array}{l}\text { Electricity and water } \\
\text { supply }\end{array}$ & 107,615 & 115,171 & 7 & 14,537 & 7.92 \\
\hline $\begin{array}{l}\text { Distribution services of } \\
\text { gaseous fuels }\end{array}$ & $\begin{array}{l}\text { Electricity and water } \\
\text { supply }\end{array}$ & 125,924 & 114,488 & -9 & 67,903 & 1.69 \\
\hline $\begin{array}{l}\text { Fabricated metal prod- } \\
\text { ucts, except machinery }\end{array}$ & $\begin{array}{l}\text { Manuf. products } \\
\text { (metals/min) }\end{array}$ & 66,117 & 104,590 & 58 & 79,618 & 1.31 \\
\hline $\begin{array}{l}\text { Transport services equip- } \\
\text { ment }\end{array}$ & $\begin{array}{l}\text { Manuf. products } \\
\text { (metals/min) }\end{array}$ & 38,244 & 99,858 & 161 & 88,686 & 1.13 \\
\hline Basic plastics & $\begin{array}{l}\text { Manuf. products (fos- } \\
\text { sil fuels) }\end{array}$ & 51,881 & 99,469 & 92 & 89,099 & 1.12 \\
\hline
\end{tabular}


Table 1 continued

\begin{tabular}{|c|c|c|c|c|c|c|}
\hline \multirow[t]{2}{*}{ Product } & \multirow[t]{2}{*}{ Product group } & \multirow{2}{*}{$\begin{array}{l}\text { MF } 1995 \\
1000 t\end{array}$} & \multirow{2}{*}{$\begin{array}{l}\text { MF } 2011 \\
1000 t\end{array}$} & \multirow{2}{*}{$\begin{array}{l}\text { \% change } \\
1995-2011\end{array}$} & \multirow{2}{*}{$\begin{array}{l}\text { FD } 2011 \\
\text { million } €\end{array}$} & \multirow{2}{*}{$\begin{array}{l}\text { Intensity } \\
2011 \\
\text { kg per } €\end{array}$} \\
\hline & & & & & & \\
\hline Sand and clay & Mining products & 110,445 & 97,418 & -12 & 1354 & 71.93 \\
\hline Ceramic goods & $\begin{array}{l}\text { Manuf. products } \\
\text { (metals/min) }\end{array}$ & 54,608 & 96,508 & 77 & 8511 & 11.34 \\
\hline \multirow[t]{2}{*}{$\begin{array}{l}\text { Leather and leather } \\
\text { products }\end{array}$} & $\begin{array}{l}\text { Manuf. products } \\
\text { (biomass) }\end{array}$ & 44,832 & 95,763 & 114 & 59,771 & 1.60 \\
\hline & $\begin{array}{l}\text { Other product } \\
\text { groups }\end{array}$ & $1,741,897$ & $2,472,081$ & 42 & $2,603,563$ & \\
\hline Total footprint & & $8,426,255$ & $12,192,456$ & 45 & $12,533,084$ & \\
\hline
\end{tabular}

The material intensities differ significantly across the various products. More than $7 \mathrm{~kg}$ of material extraction served as direct and indirect material input to produce one $€$ of final demand of cattle meat. For vegetables and fruits, it was almost 2.5 kilograms. To produce one $€$ of final demand of motor vehicles, around $1.1 \mathrm{~kg}$ of raw materials were required. The highest material intensities can be observed for mining activities, such as the extraction of sand and clay (almost 72 kilograms of extraction per $€$ of final demand in 2011).

Production layer decomposition allows investigating the material dimension of supply chains and illustrating the structure and complexity of intermediate deliveries behind the final use of a certain product or service. The numbering of the layers reflects the distance to the extraction of the various raw materials required to produce the final product, i.e., the number of intermediate deliveries before a product or service ends up in final demand. Figure 4 depicts the composition of all layers of the respective supply chains to the absolute material footprints of the 11 aggregated product groups. All layers together constitute the total footprint of a product group. In order to keep complexity on a manageable level, we illustrate Layers 0 to 4 separately and add up all higher levels in the category Layer $5+$. Table 2 complements the information in Fig. 4 by detailing the percentage contributions of each layer to the product group total, both in the year 1995 and in 2011.

As explained in Methods section above, Layer 0 only contains values for those product groups, which are directly related to material extraction activities, i.e., biomass extraction from agriculture and forestry as well as mining of fossil fuels, minerals and metal ores. These two aggregated product groups are thus the only ones that have direct deliveries from material extraction to final demand. For agriculture and forestry products, the share of Layer 0 was $56 \%$ in 2011, for mining products $72 \%$.

Material extractions taking place on Layer 1 are located one step away from the product group in focus, i.e., they represent the final intermediate deliveries before a product is being brought to its final purpose. Taking the example of the group of manufacturing products from biomass, we observe that Layer 1 has the largest contribution (31 \% in 2011). These are mainly deliveries of biotic raw materials from the agricultural sectors to food-processing sectors as well as of harvested timber to sectors producing wood-based products. 
Table 2 Share of layers in material footprint of product groups, 1995 and 2011

\begin{tabular}{|c|c|c|c|c|c|c|c|}
\hline & $\begin{array}{l}\text { Layer } 0 \\
(\%)\end{array}$ & $\begin{array}{l}\text { Layer } 1 \\
(\%)\end{array}$ & $\begin{array}{l}\text { Layer } 2 \\
(\%)\end{array}$ & $\begin{array}{l}\text { Layer } 3 \\
(\%)\end{array}$ & $\begin{array}{l}\text { Layer } 4 \\
(\%)\end{array}$ & $\begin{array}{l}\text { Layer } 5 \\
+(\%)\end{array}$ & $\begin{array}{l}\text { Material } \\
\text { footprint }(1000 \mathrm{t})\end{array}$ \\
\hline \multicolumn{8}{|c|}{ Agri. and for products } \\
\hline 1995 & 69 & 12 & 8 & 5 & 3 & 4 & 543,263 \\
\hline 2011 & 56 & 13 & 11 & 7 & 5 & 8 & 638,561 \\
\hline \multicolumn{8}{|c|}{ Mining products } \\
\hline 1995 & 78 & 15 & 3 & 2 & 1 & 1 & 295,577 \\
\hline 2011 & 72 & 17 & 4 & 2 & 2 & 3 & 334,663 \\
\hline \multicolumn{8}{|c|}{ Manuf. products (biomass) } \\
\hline 1995 & 0 & 44 & 21 & 14 & 8 & 12 & $1,521,136$ \\
\hline 2011 & 0 & 31 & 22 & 16 & 11 & 20 & $2,169,646$ \\
\hline \multicolumn{8}{|c|}{ Manuf. products (metals/min) } \\
\hline 1995 & 0 & 37 & 25 & 15 & 9 & 14 & 713,056 \\
\hline 2011 & 0 & 31 & 26 & 16 & 10 & 18 & $1,004,042$ \\
\hline \multicolumn{8}{|c|}{ Manuf. products (fossil fuels) } \\
\hline 1995 & 0 & 17 & 24 & 21 & 14 & 24 & 996,043 \\
\hline 2011 & 0 & 13 & 20 & 19 & 15 & 33 & $1,742,524$ \\
\hline \multicolumn{8}{|c|}{ Electricity and water supply } \\
\hline 1995 & 0 & 60 & 20 & 9 & 5 & 7 & 353,418 \\
\hline 2011 & 0 & 51 & 18 & 11 & 7 & 13 & 370,134 \\
\hline \multicolumn{8}{|c|}{ Construction } \\
\hline 1995 & 0 & 38 & 36 & 14 & 6 & 7 & $2,135,125$ \\
\hline 2011 & 0 & 31 & 33 & 16 & 8 & 12 & $2,834,192$ \\
\hline \multicolumn{8}{|c|}{ Sales and retail services } \\
\hline 1995 & 0 & 9 & 40 & 21 & 12 & 18 & 126,164 \\
\hline 2011 & 0 & 5 & 33 & 22 & 14 & 26 & 194,515 \\
\hline \multicolumn{8}{|c|}{ Transport services } \\
\hline 1995 & 0 & 10 & 28 & 22 & 15 & 24 & 95,321 \\
\hline 2011 & 0 & 6 & 22 & 20 & 16 & 35 & 178,545 \\
\hline \multicolumn{8}{|c|}{ Financial services } \\
\hline 1995 & 0 & 11 & 33 & 25 & 13 & 18 & 458,940 \\
\hline 2011 & 0 & 7 & 23 & 23 & 16 & 31 & 608,436 \\
\hline \multicolumn{8}{|c|}{ Other products } \\
\hline 1995 & 0 & 12 & 31 & 22 & 14 & 21 & $1,188,212$ \\
\hline 2011 & 0 & 6 & 24 & 23 & 16 & 31 & $2,117,199$ \\
\hline
\end{tabular}

Layer 2 contains extractions of raw materials, which are two intermediate steps away from the final product. An example from the construction sector, which is characterized by the largest share of inputs from Layer 2 across all aggregated product groups (33\% in 2011), is the sequence of limestone being extracted in mining, delivered as an input to cement production, with cement then purchased by construction activities.

With regard to the composition and temporal development of the structure of supply chains across the various layers, two key observations can be drawn from Table 2 . First, the distribution across the 5 analyzed layers changes across sectors, as supply chains increase in complexity. While products from the primary sectors contain by far the largest parts of inputs on Layer 0 , the manufacturing sectors typically peak on Layers 2 or 3. Services have an even higher share of high-layer extractions in their total material 
footprint. The second important conclusion concerns the changes of layer structures over time. Table 2 illustrates that in the past 20 years, supply chains across all product groups have become more complex, i.e., percentage contributions of layers with lower numbers were declining in almost all cases, whereas Layers 3-5 + gained in importance. This illustrates that supply chains are increasingly complex and differentiated in their organization, and an ever-increasing number of production steps is interlinked for the production of goods and services delivered to final demand.

Figure 5 takes the analysis one level further by illustrating to what extent the changes in the supply chain structures were linked to the overall trends of outsourcing material extraction away from the EU territory to other world regions discussed for the overall material footprint in Figs. 1 and 2. For illustrative purposes, we select two product groups with a major importance in the overall EU material footprint, i.e., construction and manufactured products based on biomass.

Figure 5 illustrates that significant geographical shifts can be observed on all layers when comparing the years 1995 and 2011, i.e., the contribution of material extractions within the EU was shrinking, while extractions in the non-EU countries gained in importance (compare the aggregated results in Figs. 1 and 2 above). Construction is a pronounced example: While $83 \%$ of extractions as inputs to construction activitiesin particular on Layers 1 and 2-were taking place within the EU borders in 1995, this value decreased to only $38 \%$ in 2011. In the latter year, significant material extractions took place in the non-EU countries on all layers. For example, on Layer 1, large material extractions outside the EU took place regarding construction minerals, such as sand and clays, which are then further processed into construction materials imported into the EU. On Layer 2, metal ores used in construction, notably iron ore, as well as fossil fuels (coal and oil) serving as energy inputs into manufacturing of construction materials play major roles.

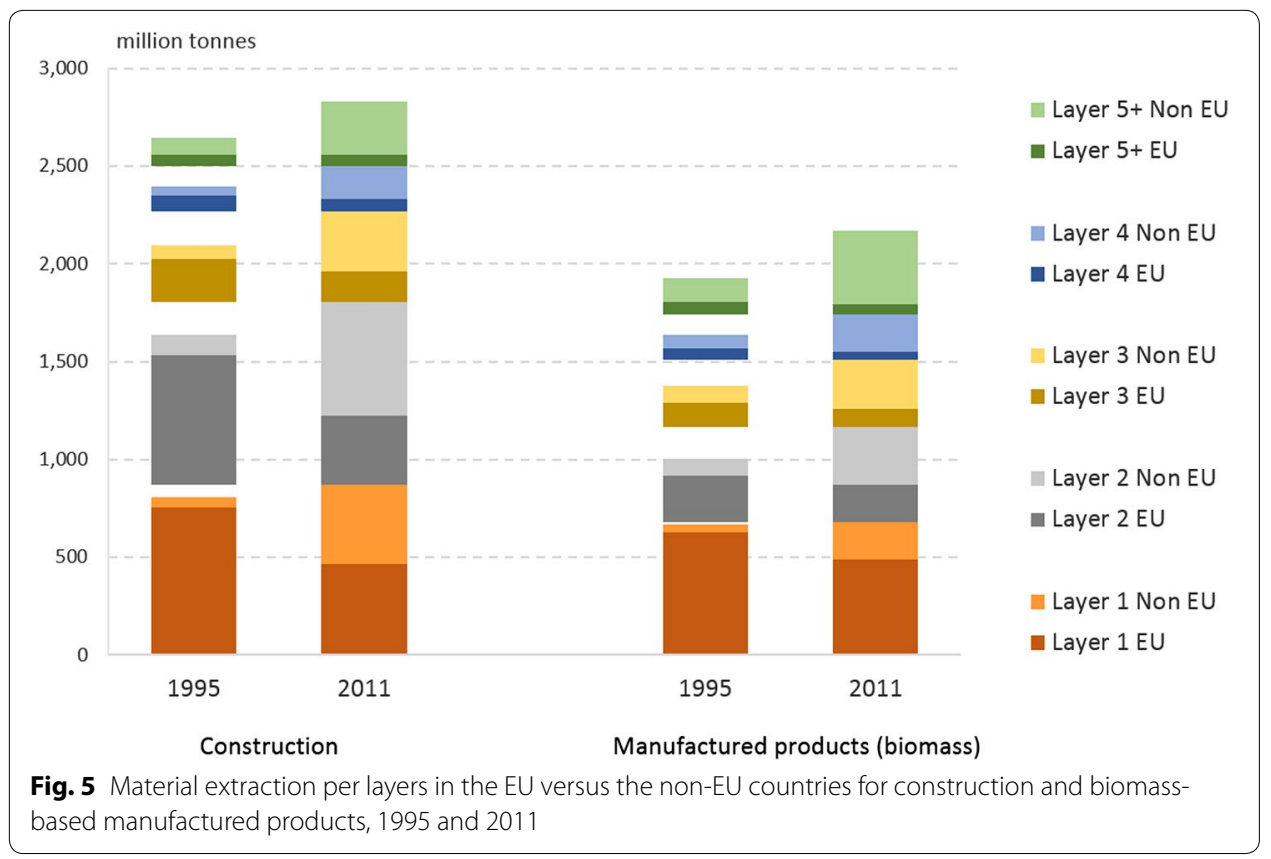


A similar, but less accentuated development could be observed for the group of manufactured products from biomass. Also here the ratio of domestic to foreign extractions changed from 73:27 \% in 1995 to 40:60 \% in 2011. However, there are still significant shares of extraction within the EU on Layer 1, indicating that the EU food- and woodprocessing industries are still to an important extent supplied by agricultural and forestry products harvested within the EU. However, raw materials for higher processed inputs to the production processes of biomass-based manufactured products are originating to a growing extent outside the EU. This trend can also be observed for other product groups.

In the final analytical step, we disaggregate the information from the layer analysis by the four main material groups of MFA. Figure 6 illustrates on which of the layers each of the four raw material groups was mainly extracted to serve the overall EU final demand for products and services in the year 2011.

We can observe different patterns across the four aggregated material categories. The use of minerals shows the steepest distribution across all layers, peaking at Layer 2 . This implies that products being produced from extracted mineral resources have relatively short supply chains (compare also the layer structure of the construction sector in Fig. 4 and Table 2). This is not surprising, as the major products from minerals are construction and industrial minerals, which are either directly delivered from the mining sector (e.g., sand and stones) or delivered from the sectors producing further processed construction materials, such as cement. Biomass also has a curve, which peaks at Layer 1, indicating that there are only one or two steps of processing before the largest share of extracted biomass is being delivered to final demand (compare the structure of the agricultural/forestry product group and the biomass-based manufactured products in Fig. 5 above). The distribution of the other two main material categories, i.e., fossil fuels and metal ores, shows a different pattern. Their slope is much lower, indicating that a larger fraction of the overall fossil and metal footprint is generated on higher layers, i.e., further away from the final product. Fossil fuels and metal ores thus mainly serve as inputs to goods and services with more complex supply chains, indicating their fundamental character for the production processes of various sectors across the whole economy.

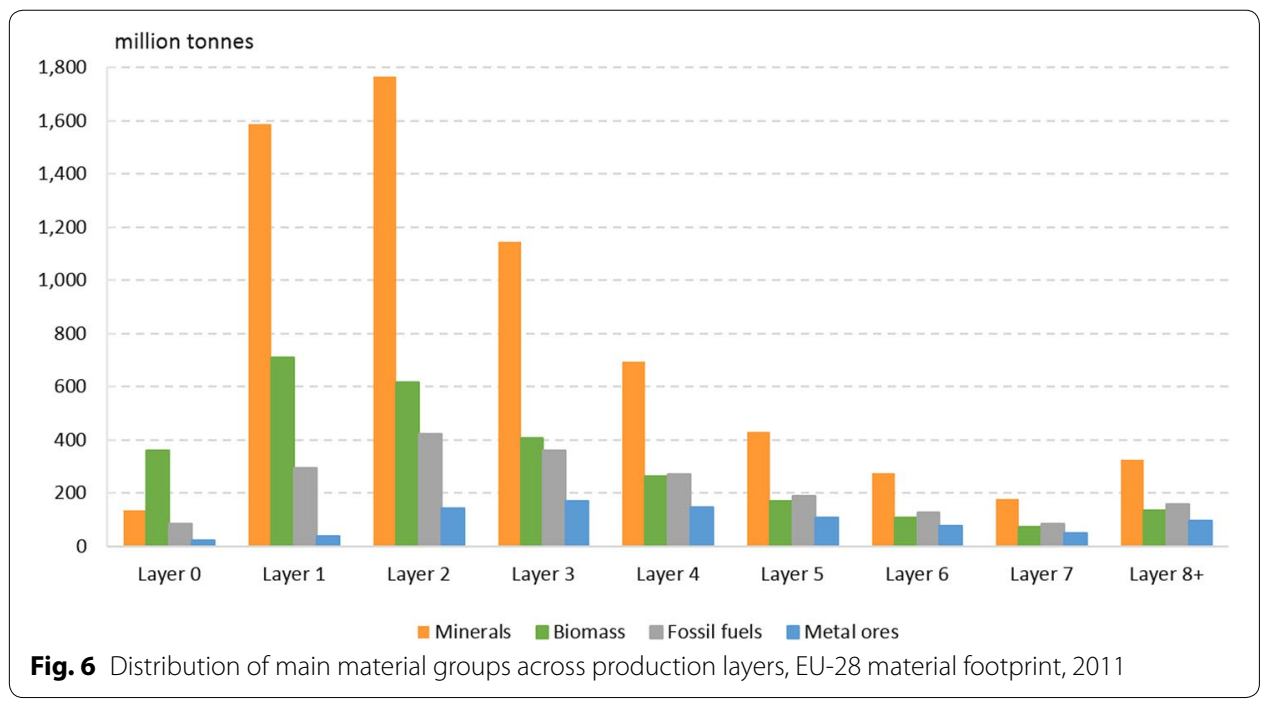




\subsection{Discussion}

\subsubsection{Priorities for European resource policies}

The results generated with the global MRIO model with detailed material extensions as applied in this paper confirm the priorities of EU resource policy initiatives with regard to product groups, i.e., we find that construction as well as the group of manufactured biomass-based products are the top 2 product groups constituting EU's material footprint. Transport services as such play only a minor role as a final demand category; however, construction activities also cover the resources used in developing transport infrastructure. Our analysis illustrated that there are important product groups in addition to the commonly known high-impact activities of construction, food and mobility. Most notably, we found that, with around a quarter of the total, the service sectors contribute a significant share to the overall material footprint of the EU. Examples for service sectors with high absolute importance are health and education services, public administration and defense as well as real-estate services. These activities are characterized by very complex supply chains, i.e., the provision of services typically requires a large variety of highly manufactured products as inputs. As the layer analysis illustrated, these products are characterized by a significant number of processing stages. The transition toward a "knowledge-based service economy" is often assumed to be an environmentally positive development. While services do have a lower material intensity per $€$ of generated added value compared to other parts of the economy (see Table 1 above and the detailed table in the Additional file 5), the growing absolute importance of the service sectors in generating European GDP, however, results in high absolute material consumption of services. This is in line with similar finding regarding the carbon footprint of countries (Hertwich and Peters 2009; Piaggio et al. 2015). A service-oriented economy thus is not automatically dematerialized or decarbonized, when taking a full supply chain perspective. This fact is currently being overlooked in the European resource policy context.

Production layer decomposition, which revealed the underlying structure of supply chains for different product groups as well as for aggregated raw material groups, also provides important insights for EU resource policies. On the one hand, the disaggregation by material groups suggests that resource policies should take into account the different levels of complexities of supply chains. Products based on minerals and biomass are characterized by less complex intermediate delivery structures compared to fossil fuels and metal ores, which serve as inputs for a large number of different products across numerous economic sectors. Given the very high levels of import dependency in these two product groups (compare Fig. 2 above), this puts the EU in a vulnerable position. On the other hand, the layer analysis illustrated that an increasing share of materials is extracted outside the EU on each of the single layers, thus pointing to the importance of considering the overall supply chain, if an absolute reduction in global material extraction related to EU consumption should be achieved.

Secondary materials from recycling activities were not explicitly considered in this study, which focused on the material footprint of primary extraction. Recent estimates illustrate that there exist huge potentials to increase the degree of circularity in the European economy. The aggregated recycling rate, calculated as the amounts of recycled materials as a share of all processed materials, was only $12.6 \%$ in 2005 (Haas et al. 
2015). An ambitious implementation of the circular economy package would reduce the European demand for primary raw materials and thus would also decrease the material footprint as presented in this paper. Moving to a circular economy is therefore also closely connected to economic issues, such as import dependence and stable supply of raw materials for European industries (European Commission 2015).

The global impacts related to material consumption in Europe are mentioned in some of the EU policy documents, most notably with regard to biomass consumption. However, the results of the MRIO-based assessments in this paper suggest that a supply chain perspective is of key importance for the EU economy, which has a higher material import dependence than all other world regions (see Giljum et al. 2015). The consumption of goods and services in the EU is to a large and rapidly growing extent dependent on indirect material extractions taking place outside the EU's territory. This has environmental implications, as raw materials originate to an increasing extent from developing and emerging economies, which often have lower levels of environmental standards compared to industrialized countries (for example, Hilson 2012). The expansion of raw material extraction activities also often leads to an increasing number of environmental conflicts with the local population, which faces, e.g., dislocations due to expansions of mining areas or accumulations of air and water pollution with severe negative effects on their daily lives (Martinez-Alier 2014). Thus, if considering pollution and other negative environmental consequences related to material extraction in impact-oriented material footprint indicators (van der Voet et al. 2009), the geographical location of raw material extraction could play an increasingly important role in determining Europe's environmental performance. Also, labor conditions are often very low in developing country activities related to agricultural production or mining, and material extraction often fosters enclave types rather than inclusive forms of development (for example, Bird 2014). As a final consumer of products to which these raw materials serve as direct and indirect inputs, Europe should acknowledge its share in the responsibility for the environmental and social conditions in other world regions. Europe could more actively engage in financial, technological and knowledge support in extraction countries to raise environmental and social standards, as underlying, for example, the idea of a Global Marshall Plan (Yunker 2014). This responsibility is currently not sufficiently assumed in EU policies related to raw materials. For example, the raw material initiative is strongly focused on securing access to resources in particular in developing countries, which sometimes contradicts the objectives of EU development policies, which aim at helping developing countries combat poverty through investing in the sustainable management of their natural resources (Heinrich Böll Foundation 2011).

\subsubsection{Methodological aspects}

The MRIO analysis performed in this paper allocates material extraction due to economic activities through the global supply chains to the final consumers. As such, MRIOs foremost rely on reliable data on domestic material extraction, as any errors or uncertainty in the extraction data are passed through the full analysis and directly affect the footprint results. Although extraction data are similar across global databases with regard to categories such as agricultural production or extraction of fossil fuels (Fischer-Kowalski et al. 2011), estimations need to be applied for quantitatively important 
categories, such as construction materials (see above and Additional file 3 for details). This calls for further international efforts to align existing estimation approaches, including the consideration of recycled construction materials (Hashimoto et al. 2009; Wiedenhofer et al. 2015).

Allocating material extraction to those industries or users extracting the material requires detailed knowledge about the composition of each industry-data that are not readily available. For example, rock aggregate is a high mass but low-value commodity that is sometimes traded and sometimes extracted directly. Allocating rock aggregate extraction to the quarrying industry, as is done in EXIOBASE, assumes that all rock aggregate is traded, whereas in some countries, quarrying may be limited to highervalue commodities, and rock aggregate may be extracted directly by the construction industry (Schaffartzik et al. 2014; Schoer et al. 2013).

High sector detail can help reducing this uncertainty (de Koning et al. 2015; Lenzen 2011). EXIOBASE provides the highest harmonized sector detail of MRIO models, but because data are not available at such detail for all countries, a combination of LCA data, proxy country IO data (from some specific, highly detailed national IO tables) and sector-specific information (e.g., energy balances from the IEA for the energy sector) was used for disaggregation (Wood et al. 2015) where regional differences can have an impact, particularly in assessments of material flows (Stadler et al. 2014).

A general caveat to current MRIO analyses is that the production of capital goods including infrastructure is not allocated to the users of the infrastructure (by sector, or over time), such that results show the annual resource requirement of various activities. This approach provides consistency with national accounting, but could be relaxed by endogenizing capital goods and infrastructure in the coefficient matrix (see Lenzen 2001) to allocate infrastructure to goods and services consumed by households and government.

\section{Conclusions}

In this paper, we provided a detailed assessment of the composition of the material footprint of the EU and its underlying supply chain structures. We argued that recent developments in the compilation of multi-regional input-output databases open up a range of new analytical options for the assessment of global material flows related to final consumption of a country or world region. A particular strength of the MRIO approach to analyze material flows is the possibility to identify the most important products and product groups contributing to the material footprint as well as to investigate the international supply chains underlying the final goods and services delivered to final demand through applying production layer decomposition. This type of analysis goes far beyond the calculation of headline indicators on material consumption and material productivity, which so far has dominated the MFA literature, and allows connecting much better to issues related to the development of resource policies, which are currently emerging in the context of European policy making.

The objective of this paper was to provide an illustration of the analytical potentials starting from the macro-level of the overall EU material footprint and disaggregating it in several dimensions. However, there is still a lot of room to expand this type of research further and to derive more specific results. One option is to focus the analysis on single 
raw materials instead of aggregated material groups. Full structural path analysis (SPA) could also be applied for selected products of particular policy relevance, in order to identify hotspots of material extraction on each layer of the supply chain, for example, with regard to service sectors with important contributions to the overall material footprint. Finally, it is important to continue work on uncertainty analyses in connection with material footprint models based on various MRIO databases.

\title{
Additional files
}

Additional file 1: Full list of EXIOBASE products and product groups.

Additional file 2: Full list of EXIOBASE countries and regions.

Additional file 3: Technical details on the compilation of the global material flow database.

Additional file 4: Correspondence table between raw materials and EXIOBASE sectors.

Additional file 5: Detailed material footprint (MF) results.

\begin{abstract}
Author details
${ }^{1}$ Institute for Ecological Economics, Vienna University of Economics and Business (WU), Vienna, Austria. ${ }^{2}$ Industrial Ecology Programme, Norwegian University of Science and Technology (NTNU), Trondheim, Norway. ${ }^{3}$ Institute of Environmental Sciences (CML), Leiden University, Leiden, The Netherlands. ${ }^{4}$ Netherlands Organisation for Applied Scientific Research (TNO), Delft, The Netherlands.
\end{abstract}

\section{Acknowledgements}

We acknowledge financial support for this research from the European Commission through the FP7 project DESIRE "Developing a system of indicators for a resource efficient Europe" (Project Number: 308552).

\section{Competing interests}

The authors declare that they have no competing interests.

Received: 13 August 2015 Accepted: 14 May 2016

Published online: 06 June 2016

\section{References}

Acosta-Fernández J (2007) Identifikation prioritärer Handlungsfelder für die Erhöhung der gesamtwirtschaftlichen Ressourcenproduktivität in Deutschland [Identification of priority areas of action for increasing economy-wide resource productivity in Germany]. Wuppertal Institut, Wuppertal

Andrew RM, Peters GP (2013) A multi-region input-output table based on the global trade analysis project database (GTAP-MRIO). Econ Syst Res 25:99-121

Arto I, Genty A, Rueda-Cantuche JM, Villanueva A, Andreoni V (2012) Global resources use and pollution: vol. I, production, consumption and trade (1995-2008), JRC scientific and policy reports. European Commission Joint Research Centre (IPTS), Luxembourg

Bird F (2014) The practice of mining and inclusive wealth development in developing countries. J Bus Ethics 1-13

Bruckner M, Giljum S, Lutz C, Wiebe K (2012) Materials embodied in international trade-global material extraction and consumption between 1995 and 2005. Glob Environ Change 22:568-576

de Koning A, Bruckner M, Lutter S, Wood R, Stadler K, Tukker A (2015) Effect of aggregation and disaggregation on embodied material use of products in input-output analysis. Ecol Econ 116:289-299

European Commission (2008) The raw materials initiative. Meeting our critical needs for growth and jobs in Europe. COM (2008) 699. European Commission, Brussels

European Commission (2011a) Analysis associated with the roadmap to a resource efficient Europe. Part 1. European Commission, Brussels

European Commission (2011b) A resource-efficient Europe-flagship initiative under the Europe 2020 strategy, $\operatorname{COM}(2011)$ 21, communication from the Commission to the European Parliament, the Council, the European Economic and Social Committee and the Committee of the Regions. European Commission, Brussels

European Commission (2011c) Roadmap to a resource efficient Europe. European Commission, Brussels

European Commission (2011d) Tackling the challenges in commodity markets and on raw materials. European Commission, Brussels

European Commission (2015) Closing the loop_an EU action plan for the circular economy. European Commission, Brussels

EUROSTAT (2013) Economy-wide material flow accounts (EW-MFA). Compilation guide 2013. Statistical Office of the European Communities, Luxembourg

Fischer-Kowalski M, Krausmann F, Giljum S, Lutter S, Mayer A, Bringezu S, Moriguchi Y, Schütz H, Schandl H, Weisz H (2011) Methodology and indicators of economy-wide material flow accounting. J Ind Ecol 15:855-876 
Giljum S, Dittrich M, Lieber M, Lutter S (2014) Global patterns of material flows and their socio-economic and environmental implications: a MFA study on all countries world-wide from 1980 to 2009. Resources 3:319-339

Giljum S, Bruckner M, Martinez A (2015) Material footprint assessment in a global input-output framework. J Ind Ecol 19:792-804

Graedel T, Harper E, Nassar N, Nuss P, Reck BK (2015) Criticality of metals and metalloids. Proc Natl Acad Sci $112: 4257-4262$

Haas W, Krausmann F, Wiedenhofer D, Heinz M (2015) How circular is the global economy? An assessment of material flows, waste production, and recycling in the European Union and the world in 2005. J Ind Ecol 19:765-777

Hashimoto S, Tanikawa H, Moriguchi Y (2009) Framework for estimating potential wastes and secondary resources accumulated within an economy - A case study of construction minerals in Japan. Waste Manag 29:2859-2866

Heinrich Böll Foundation (2011) Analysis of the EU raw materials initiative. Heinrich Böll Foundation, Berlin

Hertwich EG, Peters GP (2009) Carbon footprint of nations: a global, trade-linked analysis. Environ Sci Technol 43:6414-6420

Hilson G (2012) Corporate Social Responsibility in the extractive industries: experiences from developing countries Resour Policy 37:131-137

Kovanda J, Weinzettel J (2013) The importance of raw material equivalents in economy-wide material flow accounting and its policy dimension. Environ Sci Policy 29:71-80

Krausmann F, Gingrich S, Eisenmenger N, Erb K-H, Haberl H, Fischer-Kowalski M (2009) Growth in global materials use, GDP and population during the 20th century. Ecol Econ 68:2696-2705

Laner D, Feketitsch J, Rechberger H, Fellner J (2015) A novel approach to characterize data uncertainty in material flow analysis and its application to plastics flows in Austria. J Ind Ecol. doi:10.1111/jiec.12326

Lenzen M (2001) A generalized input-output multiplier calculus for Australia. Econ Syst Res 13:65-92

Lenzen M (2007) Structural path analysis of ecosystem networks. Ecol Model 200:334-342

Lenzen M (2011) Aggregation versus disaggregation in input-output analysis of the environment. Econ Syst Res 23:73-89

Lenzen M, Crawford R (2009) The path exchange method for hybrid LCA. Environ Sci Technol 43:8251-8256

Lenzen M, Gallego B, Wood R (2009) Matrix balancing under conflicting information. Econ Syst Res 21:23-44

Lenzen M, Wood R, Wiedmann T (2010) Uncertainty analysis for multi-region input-output models-a case study of the UK's carbon footprint. Econ Syst Res 22:43-63

Lenzen M, Moran D, Kanemoto K, Geschke A (2013) Building EORA: a global multi-region input-output database at high country and sector resolution. Econ Syst Res 25:20-49

Lettenmeier M, Liedtke C, Rohn H (2014) Eight tons of material footprint-suggestion for a resource cap for household consumption in Finland. Resources 3:488-515

Llop M, Ponce-Alifonso X (2015) Identifying the role of final consumption in structural path analysis: an application to water uses. Ecol Econ 109:203-210

Lutter S, Giljum S, Bruckner M (2016) A review and comparative assessment of existing approaches to calculate material footprints. Ecol Econ 127:1-10

Martinez-Alier J (2014) The environmentalism of the poor. Geoforum 54:239-241

Narayanan G, Badri AA, McDougall R (eds) (2015) Global trade, assistance, and production: the GTAP 9 data base. Center for Global Trade Analysis, Purdue University, West Lafayette, IN

OECD (2007) Measuring material flows and resource productivity. The OECD guide. Environment Directorate. Organisation for Economic Co-operation and Development, Paris

OECD (2011) Towards Green Growth: Monitoring Progress. OECD Indicators. Organisation for Economic Cooperation and Development, Paris

Peters GP, Hertwich EG (2006) Structural analysis of international trade: environmental impacts of Norway. Econ Syst Res 18:155-181

Piaggio M, Alcántara V, Padilla E (2015) The materiality of the immaterial: service sectors and $\mathrm{CO}_{2}$ emissions in Uruguay. Ecol Econ 110:1-10

Schaffartzik A, Eisenmenger N, Krausmann F, Weisz H (2014) Consumption-based material flow accounting. Austrian trade and consumption in raw material equivalents 1995-2007. J Ind Ecol 18:102-112

Schoer K, Weinzettel J, Kovanda J, Giegrich J, Lauwigi C (2012) Raw material consumption of the European Union—concept, calculation method, and results. Environ Sci Technol 46:8903-8909

Schoer K, Wood R, Arto I, Weinzettel J (2013) Estimating Raw Material Equivalents on a macro-level: comparison of multiregional input output analysis and hybrid LCA-IOA. Environ Sci Technol 47:14282-14289

Stadler K, Steen-Olsen K, Wood R (2014) The "rest of the world"—estimating the economic structure of missing regions in global multi-regional input-output tables. Econ Syst Res 26:303-326

Steinberger JK, Krausmann F, Getzner M, Schandl H, West J (2013) Development and dematerialization: an international study. PLoS One 8:e70385

Tukker A, de Koning A, Wood R, Hawkins T, Lutter S, Acosta J, Rueda Cantuche JM, Bouwmeester M, Oosterhaven J, Drosdowski T (2013) EXIOPOL — development and illustrative analyses of detailed global MR EE SUT/IOT. Econ Syst Res 25:50-70

Tukker A, Bulavskaya T, Giljum S, de Koning A, Lutter S, Silva Simas M, Stadler K, Wood R (2014) The global resource footprint of nations. Carbon, water, land, and materials embodied in trade and final consumption calculated with EXIOBASE 2.1. Leiden/Delft/Nienna/Trondheim

UNEP (2011a) Decoupling natural resource use and environmental impacts from economic growth, A report of the Working Group on Decoupling to the International Resource Panel. Fischer-Kowalski M, Swilling M, von Weizsäcker EU, Ren Y, Moriguchi Y, Crane W, Krausmann F, Eisenmenger N, Giljum S, Hennicke P, Romero Lankao P, Siriban Manalang A, Sewerin S. UNEP, Paris

UNEP (2011 b) Towards a green economy. Pathways to sustainable development and poverty eradication. UNEP, Nairobi

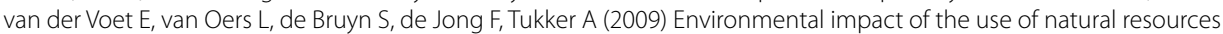
and products. CML, Leiden 
Wang H, Tian X, Tanikawa H, Chang M, Hashimoto S, Moriguchi Y, Lu Z (2014) Exploring China's materialization process with economic transition: analysis of raw material consumption and its socioeconomic drivers. Environ Sci Technol 48:5025-5032

Wiedenhofer D, Steinberger JK, Eisenmenger N, Haas W (2015) Maintenance and expansion: modeling material stocks and flows for residential buildings and transportation networks in the EU-25. J Ind Ecol 19:538-551

Wiedmann TO, Lenzen M, Barrett JR (2009) Companies on the scale. Comparing and benchmarking the sustainability performance of businesses. J Ind Ecol 13:361-383

Wiedmann T, Schandl H, Lenzen M, Moran D, Suh S, West J, Kanemoto K (2015) The material footprint of nations. Proc Natl Acad Sci (PNAS) 112:6271-6276

Wood R, Stadler K, Bulavskaya T, Lutter S, Giljum S, de Koning A, Kuenen J, Schütz H, Acosta-Fernández J, Usubiaga A (2015) Global sustainability accounting — developing EXIOBASE for multi-regional footprint analysis. Sustainability 7:138-163

WU (2015) Global material flow database (www.materialflows.net). Material extraction data. Technical report, version 2015.1. Vienna University of Economics and Business (WU), Vienna

Yunker JA (2014) Global Marshall plan: theory and evidence. Lexington Books, New York

\section{Submit your manuscript to a SpringerOpen ${ }^{\mathcal{O}}$} journal and benefit from:

- Convenient online submission

\section{- Rigorous peer review}

- Immediate publication on acceptance

- Open access: articles freely available online

- High visibility within the field

- Retaining the copyright to your article

Submit your next manuscript at $\boldsymbol{\nabla}$ springeropen.com 